\title{
US patent application stirs up gene hunters
}

- NIH researcher files for 337 genes at one time - When should a gene be patentable?

\section{Washington}

UNTIL this summer, no one worried much about patenting human genes. Cystic fibrosis, muscular dystrophy, Huntington's disease, whatever - map it, sequence it, take it to the patent office. Unless someone complained about apportionment of credit, gene patenting was business as usual.

Then, on 20 June, Craig Venter dropped a 400-page application on the US Patent Office. With a single filing, Venter requested patents for 337 new human genes -DNA fragments that his automatic gene sequencers at the National Institutes of Health (NIH) had cranked out in just months, almost unaided. In a few years, he said, he could come back with most of genes in the entire human genome.

Now, three months later, gene hunters are bracing for a patent 'gold rush'. Researchers around the world have suddenly developed an interest in the working of the Patent Office - as well as in Venter's simple technique, which is based on sequencing only the DNA that is actually expressed in an organism, known as complementary DNA, or cDNA. With a laboratory full of robotic gene machines, Venter can sequence 75 kilobases of cDNA a day, including perhaps 100 new genes. He has virtually no idea what the individual genes do, but they must do something. Any given one of them could be linked to some form of cancer, Alzheimer's disease or some other genetic defect.

"If these things are patentable, there's going to be an enormous cDNA arms race," predicted Max Hensley, senior attorney for the biotechnology company Genentech, at a gene sequencing conference in South Carolina last month. Hensley thinks that might not be such a bad thing. "If we get an entire cDNA library, what's wrong with that?" But many other influential people find plenty not to like about Venter's work, cDNA sequencing and the prospect of patenting genes by the pound.

"I think it's a terrible idea," says Maynard Olson, a Washington University geneticist and member of the Genome Project's advisory panel. "If the law is interpreted to give intellectual property rights for naked DNA sequences, then the law should be changed. It's like trying to patent the periodic table. To put patent value on cream-skimming is sending entirely the wrong signal. Scientists who advocate such approaches are playing with fire." James Watson, director of the National Center for Human Genome Research at NIH, has called cDNA patenting "outrageous".

Some scientists argue that the wholesale patenting of DNA sequences when their function is still unknown is an abuse of the patent system. "Patent law wasn't designed to be a kind of lottery where one guesses every large number of letters that might be the right combination," Olson says. Others are afraid of the "chilling effect' that commercialization of gene sequences so early in the process might have on future industrial investment. Still others are concerned that patenting costs will drain money from research, that researchers may withhold data until their patent is granted or that patents will force countries to compete, rather than collaborate, in the race to lock up the entire genome.

But underlying much of the concern is the sense that large-scale cDNA sequencing is just not sporting. The Genome Project was sold to Congress as a 15-year, $\$ 3,000$-million effort to map and sequence the entire human DNA molecule. Now Venter says he can get almost all the genes - the only part of the genome most congressmen care about - in a few years, for perhaps $\$ 10$ million. Venter is quick to emphasize that cDNA sequencing is no substitute for mapping, and that finding the location and the function of the genes will be essential to the project. But once that is done, convincing Congress that another $\$ 2,500$ million still needs to be spent on sequencing the rest of the genome - the 97 to 98 per cent that contains no genes - might be difficult.

"There's an undercurrent of tension between those who advocate a cDNA approach and those who advocate the heavyweight sequence-to-the-end approach," says one industry observer. "Venter says he can do it cheaply. But the glory of it all gets dissipated to the wind once you've sequenced all the genes. It's a matter of who leads the project. The patent issue is just a lightning rod on the whole controversy."

For the moment, all eyes are on the

\section{To patent a naked gene}

IN biotechnology, as in any other field, an invention must satisfy three basic criteria to win a patent. It must be novel, it must be nonobvious, and it must have some utility.

Craig Venter's patent application for 337 new genes (see above) does appear to be novel. He has searched all the available databases for matches and the genes seem never to have been sequenced before.

But obviousness is a trickier issue. Venter invented neither the concept of sequencing cDNA nor the technology that allows him to do it so easily, and application of known technology in a standard way is classic obviousness. Venter's insight, however, was that largescale cDNA sequencing, combined with the searching ability of electronic DNA databases, could generate human genes at an unprecedented rate, and that must be worth something, NIH lawyers argue.
"Patent law specifically says that you can't consider how the invention was made," says Reid Adler, the NIH technology-transfer expert who handled Venter's patent. "It's irrelevant if a trained chimpanzee can do the work. The law doesn't want some judge deciding if someone sweated enough to deserve a patent."

Perhaps the toughest hurdle for Venter's sequences is utility. His genes are 'naked' - merely expressed DNA whose function is unknown. "We argue that you could use the sequence as a probe or to distinguish brain tissue from other tissue," says Adler, but he admits that this is less than an airtight claim. For one thing, although all of Venter's cDNA samples come from brain tissue, many of the sequences probably code for common 'housekeeping' genes that can be found anywhere in the body. They would be no help in identifying brain tissue.
"This is not the strongest case for utility I've ever seen, but it's not the weakest either," Adler says. "It was worth filing the application, if for no other reason than not to miss the boat."

Other patent lawyers agree. "I would hate to be the NIH administrator that has to explain why the UK or Japan were able to obtain a patent when the US didn't even try," says one.

Nevertheless, the application is considered a long shot. Although patent office biotechnology expert Charles Van Horn would not comment on the specific application, he raised concerns about the general idea of patenting fragments of unknown genes. "Is it specific [to a particular gene]? Without that kind of information, it is not patentable. In the chemical side, this has been tried without clear utility — and it hasn't been patented," he says.

C.A. 
Patent Office, which must decide whether or not to approve Venter's application (see page 485). But assuming for the moment that a patent is granted, there remains the question of whether patents for unmapped genes are a good thing, in any form. Venter argues that a patent ensures that a gene will be available for all researchers and for any company willing to license it.

Simply placing a sequence in the public domain, as most researchers now do when they publish it and submit it to a database, usually means that no company can get a patent on the gene unless it has near-clinical use, such as identifying its expression products or developing a test based on it. Even then, patents based on 'methods of use' tend to be open to challenge. Few companies are likely to risk millions of dollars in development costs on a gene product they may not be able to patent. On the other hand, if Venter's patent turns out to be just the first of a string of ever more specific patents as the gene is progressively characterized, then that is just one more expense and complication, and another question mark for a prospective investor. "What if the gene turns out to be linked to another gene that the French have licensed?" asks one biotechnology lawyer. "I'm not going to invest a million dollars with that kind of uncertainty."

Since June, Venter has found nearly 2,000 more genes, and a second patent application is in the works, something that seems likely to fan the flames of the controversy. Hoping to air some of the issues, the NIH technology transfer office will hold a one-day conference, to which the public and industry are invited, on 14 November. And in the meantime, NIH is considering asking the Patent Office for expedited consideration of the application, which could generate a decision in six months, rather than the usual two years.

Whatever the conclusion, Venter seems to have made his point: cDNA has a place in the genome project. Next month, the Genome Center will consider its first applications for cDNA sequencing. (The Department of Energy and the National Institute of Neurological Disorders and Stroke, where Venter works, have been funding cDNA work for several years.)

"If the patent office allows Venter's application, by far the greatest return on investment would be to patent cDNA," says Thomas Caskey, a Baylor College of Medicine genetics researcher. "It's a huge gamble to make an error on this." The fact that one-fifth of France's new \$20 million genome effort will be aimed at cDNA sequencing, as is much of the UK, European Communities and Japanese programmes, has not gone unnoticed, either. "If the patent office says yes," predicts Caskey, "then it's Katy bar the door."

Christopher Anderson

\section{Inspace, no onecan hearyou oink}

\section{Washington}

THANKs to Congress, US astronauts will soon not only have fewer of those annoying science projects to worry about, but they may also have their choice of Coke or Pepsi in orbit. This news may come as some surprise to the crews, however. Not only did the National Aeronautics and Space Administration (NASA) not ask for an 'advanced liquid dispensing technology evaluation', but agency officials know almost nothing about it. So why is it in NASA's new 1992 budget? Because the soft drink manufacturers lobbied key members of the Senate Appropriations committee, who quietly inserted the language last month into the funding bill.

In total, members of the House and Senate appropriations committees put more than a dozen unsolicited projects into the space budget to steer NASA money into their own home districts, a process known as 'pork barrel' funding. Last week, two peeved congressmen finally decided to take them on. In speeches on the House floor, Robert Walker (Republican, Pennsylvania) and George Brown (Democrat, California) savaged their colleagues for earmarking \$137 million in the budget in the same year that they eliminated or delayed at least ten space science projects, claiming lack of funds.

The earmarked projects "were never requested by the administration, never authorized, and never discussed on the floor," complained Brown. Yet the appropriations committees found themselves unable to afford real NASA programmes such as the space infrared telescope, the orbiting solar laboratory, the aerospace plane and the flight telerobotic server. "These are all projects that scientists have spent decades planning and developing. These are all projects that could have been funded with a little more restraint on the part of the conferees," Brown charged.

Some of the chief offenders on the Brown and Walker pork barrel hit list are: - \$20 million for the Christopher $\mathrm{Co}$ lumbus Center for Marine Research in Baltimore, Maryland, home district of Barbara Mikulski, chair of the Senate appropriations subcommittee for NASA. Although Mikulski failed to get this in the National Oceanic and Atmospheric Administration budget last year, she had better luck this year with NASA. The space agency is now in the marine research field, whether it likes it or not.

- \$28.4 million for the Consortium for International Earth Science Network in Michigan, home of Bob Traxler, chairman of the House appropriations subcommittee for NASA. Total funding for this project is now more than $\$ 41$ million, "all awarded without adequate competitions and virtually no congressional oversight," Brown protested. "NASA itself has little idea where this funding is going."

- \$22.5 million for the National Technology Transfer Center and $\$ 7.5$ million to equip a "classroom of the future" at the 1,400-student Wheeling Jesuit College, both in West Virginia, home of Senate Appropriations chairman Robert Byrd, who has promised to bring $\$ 1,000$ million in earmarked projects to the state and is well on his way to succeeding. This year's total from the NASA budget alone is $\$ 42$ million.

Christopher Anderson

\section{'Sunlight' sees Sun in a different light}

THIS image of the Sun's corona was taken by the Soft X-Ray Telescope aboard the Japanese satellite $y \bar{o} k \bar{o}$ ('sunlight') after it was launched on $30 \mathrm{Au}$ gust from the Kagoshima space centre in Japan ( $\mathrm{Na}$ ture 353, 102;12 September 1991). The telescope ajoint experiment between scientists at Japan's $\mathrm{Na}$ tional Astronomical Observatory and the US National Aeronautics and Space Administration, reveals de tails of the X-ray corona. Soft $X$-rays are produced when the temperature of the gases exceeds about 2 million degrees Fahrenheit. The loop-like structures in

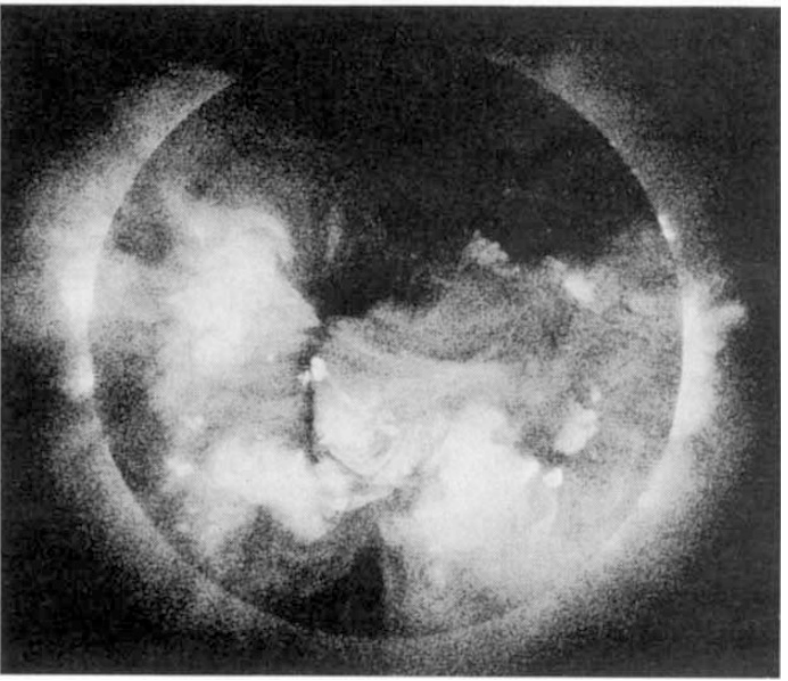

the photograph are formed by the Sun's magnetic field shaping hot coronal gases into 'magnetic bottles', and the brightness of the loops indicates the temperature and the density of the gases within them. In visible light, large sunspots would appear under the brightest loops. 